\title{
On Tendencies in the Modern Art Culture of Siberia (Based on Music-Spectacular projects Projects of Tuva)
}

\author{
Ekaterina K. Karelina* \\ Novosibirsk State Conservatory of M.I. Glinki \\ 31 Sovetskaia Str., Novosibirsk, 630099, Russia
}

Received 18.03.2018, received in revised form 02.08.2018, accepted 15.08.2018

\begin{abstract}
The article is devoted to the trends in the modern art culture of Siberia. The throat singing art of the Tuvans, one of the indigenous ethnic groups of Siberia, has been acknowledged at the international level. The latest events in the musical and cultural life of the Republic of Tuva have not become a research object for musicology yet, so the article addresses the phenomena of the last decade's musical culture of the Republic of Tuva. It considers the genre problem of modern Tuvan art. The research methodology is based on the systematic approach, combined methods of musical and cultural analysis. The purpose of the article is to determine the genre specificity of musical and spectacular projects. The material was musical stagings или тиsical dramatizations, choreographic performances and concert programs of orchestral groups (Tuvan National Orchestra, the Brass Band and the Symphonic Orchestra). The author notes the interest for the underlying fundament of ethnic culture and puts forward the concept of "syncresis of the second order" in the analysis of ethnoballets, programs of "Sayany" National Ensemble of Song and Dance and Tuvan National Orchestra. Creative projects of the Brass Band are characterized by the manifestation of the so-called "crossover" phenomenon. A special genre mix (musical-visual art-poetry) was demonstrated by the "The Wind's Song of the Age of Change..." project of the symphonic orchestra. As a result, the article presents the evaluation of different genre modifications in Tuvan musical art from the position of interaction between different types of cultures, searching for new meanings of addressing the ethno-archaic culture. In this context, modern creativity is a sort of a channel for transmitting axiological meanings of Siberian ethnic cultures into the global cultural space.
\end{abstract}

Keywords: Siberia, Tuva, modern culture, music-spectacular projects, ethnoballet, concert programs, syncresis of the second order, genre mix.

Research area: art history and culturology.

Citation: Karelina, E.K. (2018). On tendencies in the modern art culture of Siberia (based on music-spectacular projects of Tuva). J. Sib. Fed. Univ. Humanit. soc. sci., 11(8), 1262-1273. DOI: $10.17516 / 1997-1370-0305$.

(C) Siberian Federal University. All rights reserved

* Corresponding author E-mail address: ye_karelina@mail.ru 


\section{Introduction}

Modern artistic culture of Siberia is developed within a complicated intertwining of various ethnical, regional, all-Russian, and global tendencies, merging them into a compound alloy, with a specific proportion observed in each individual case in a large city or a regional entity. At the same time, there are some general tendencies, obviously manifested in the trend known as "Siberian ethnoarchaics" (Lomanova, 2015). The art traditions of the indigenous Siberian peoples have confidently manifested themselves: inter alia, the musical art of Tuvans, and particularly the throat singing art of khöomei, developing its innovative forms, has been globally acknowledged.

According to the metaphor suggested by the music producer M. Shaposhnikov, "Tuvan music stormed into the world consciousness like a herd of Mongols". (Shaposhnikov, 2017: 139). As an actual witness of the described events, the author studies the transformation process of khöommei $i^{1}$ on the basis of her experience, and, as a practitioner, attempts to forecast its further development in the space of the so-called World Music.

The fact of international recognition of the Tuvan khöömei is also proved by researches by foreign authors. Among the latest ones, it is worthwhile to mention the profound article by the American ethnomusicologist Robert Beahrs, who remarks the role of Tuvan musicians in the development of music traditions of Siberia and Inner Asia (Beahrs, 2017)2. The method of intercultural communication bringing Tuvan music to the attention of the global community is studied by Terada Mao, a Japanese researcher living in Tuva (Terada, 2017) .

\section{Statement of the problem and methods}

There are few researchers (among both foreign and Russian ones) who concentrate on the fact that the Tuvan music presented as traditional is not traditional as such; it

\footnotetext{
Analysing the reasons of the success gained by Tuvan folk bands abroad from the music management point of view, the author of the article presents an interesting idea: "These are not the stars that have conquered the skies of the Western market that make the value of Tuvan music, but the establishment of a stable community of people inspired with this music and culture, seeking for new ways of aesthetic and spiritual world perception" (Shaposhnikov, 2017: 136).

2 "The success of Tuvan music has also prompted a new wave of interest in indigenous music across Siberia and Inner Asia, most notably in Inner Mongolia (China), where a number of ensembles of traditional musicians have recently formed, and whose musical instruments, arrangements, aesthetics, and xöömei throat-singing styles draw considerably from Huun-Huur-Tu and Tuva's rich nomadic sonic-musical culture" (Beahrs, 2017: $100)$.

3 "To our mind, research of the "transculturation" (intercultural interaction), where the traditional Tuvan music is "mastered" by musicians from different countries and transformed into new artistic forms spreading all over the world, is also promising" (Terada, 2017: 217).
} 
is an innovative form ${ }^{1}$, related to the original tradition only due to its intonational and melodious basis ${ }^{2}$.

Though the world music concept is extremely popular among musicians, it is not a terminological basis for analysing modern cultural phenomena; the insufficiency of this term was fairly remarked by the British sociologist Jo Haynes, who had collected large empiric material presented in her article (Haynes, 2010: 92). The author considers the racial problem of the music art, which has become quite acute and widely discussed in the modern Tuvan culture: this is the problem of the ethnical nature of khöomei and the possibility of adequate khöömei performance by people belonging to other ethnicities. To our mind, the inclination of culture bearers to explain the throat singing talent by genetic heritage ("it's in our blood", "this is the art of our ancestors we carefully preserve" etc.) starts a complicated interaction with the global tendency manifested in the creative work of Tuvan musicians and described by Jo Haynes as "ambivalence towards ethno-cultural hybridity" (Haynes, 2010: 96).

Moreover, besides folklore, the musical culture of Tuva encompasses other kinds and genres of music, for some reason ignored by foreign researchers. Being a typical peculiarity of Tuvan musical culture, late integration into all-Russian cultural space delayed the emergence of author's composition of a new European type. Analysing the implementation of the "Soviet type" (conceptually, Eurocentric) music culture in Tuva, we could not but admit its inflexibility and event inadequacy to the cultural context where it was implemented with the political efforts and resolutions (Karelina, 2018). To our mind, the root of the problem is the original mismatch of the constructed institutional model to the musical culture of the certain local sociocultural situation; the objective reason is that, despite all historical and cultural transformations of the period, the music tradition of the Tuvans remained the same almost in all musical genres and preserved the same traditional set of instruments. Considering this fact as well as incompleteness of implementation of the selected cultural model, the functional changes demonstrated by the major music institutions of Tuva are quite predictable

It is not a coincidence that R. Beahrs puts the words "authentic" and "neotraditional" in the text of his article in quotes ("'authentic' Tuvan musical practices", "Huun-Huur-Tu's 'neotraditional' music projects"); however, the only term he listed in the key words of his works was "traditional music" (Beahrs, 2017: 60, 99), though the research focuses more on the innovative forms of Tuvan music traditions.

2 We have studied this phenomenon of folklorism through the prism of the term of "new minstrelation" (Karelina, 2009: 455-465). To a certain extent, the American art critic E. Stone agrees with the opinion: "It is my view that claims to cultural continuity of throat singing as static, timeless tradition serve as a strategy of legitimization for newly formed cultural practices" (Stone, 2012: 76). 
(Karelina, 2018). In many ways, it determines the vector of modern development of music art in the Republic, while folklore is still dominating ${ }^{1}$.

The monograph of the author is dedicated to the multiaspect analysis of Tuvan music culture development (Karelina, 2009); however, it has been almost ten years since it was published, and many musical and cultural events held in the Republic since 2009 have not been analysed from the musical point of view, noticed by the mass media only. For this reason, the subject of the article are the musical cultural phenomena at the modern historical stage of development of the Republic of Tuva (initially, the 2010-s), and the object is the problem of genre determination of a whole series of creative projects, being bright events in the cultural life of the Republic. The optimal method of the research is relying on the systematic approach combined with structural-typological, structural-functional and inclusive observation methods. The purpose of the research is determination of genre specificity of the creative projects by comparing musical observations to the cultural context. The analysis was based on musical and theatre productions, as well as orchestra concert programmes.

\section{Discussion}

Among large-scale contemporary Tuvan musical cultural projects there are socalled ethnoballets, being a special variety of the ballet genre at the intersection of ballet as such, choreographic performance and suite. Among them, there are: children's ballet "Shyiaan am..." (untranslatable fairy tale introduction; music by a group of young composers, produced by the Children's Choreographic School of Kyzyl in 2011) ${ }^{2}$ and musical and choreographic performance "Duyuiaalyg Turug" ("The Crane Rock", music by B.-M. Tulush, produced by "Sayany" National Ensemble of Song and Dance, 20173). Just like the first Tuvan ethnoballet "Khaia Mergen" (1979), "Duyuiaalyg Turug” is based on folk legends and tales, with a throat-singing Storyteller involved in the performance. Tuvan dance culture researcher Irina Ondar remarks: "Reliance on folk legends, plots, traditions, customs, rituals is a regular feature of post-Soviet Tuvan art" (Ondar, 2016: 134). The ethnocultural originality of Tuvan ballets is majorly determined

\footnotetext{
At that, a number of folklore musicians realize the necessity to expand the genre and stylistic diapason of throat singing use. Master's student from Texas E. Stone quotes the opinion of khöömei expressed by "Chirgilchin" folk-group soloist Aldar Tamdyn: "It should be used in jazz, blues, rock, opera. Why not? We have to do this otherwise it is no longer a tradition. Sure people can use throat singing to chant, meditate, shamanize and all that, but to only look at throat singing as a mystical tool limits the possibilities of this incredible practice" (Stone, 2012: 79).

2 For more details of the ballet, see Article (Karelina, Ondar, 2012).

3 The performance was shown for the first time on the stage of V.Sh. Kok-ool Tuvan Music and Drama Theatre on November 15, 2017; the performance was repeated on January 26, 2018.
} 
by the storytelling tradition, which, according to the culturologist choreographer, "helps the spectator understand the conventional language of ballet performance" (Ondar, 2016: 134). The musical solution of the latter was highly appreciated by the ethnomusicologist Zoya Kyrgys, who remarked the organic connection of the plastic pattern of the performance to its musical appearance ${ }^{1}$.

The more "undetermined" genres are those of the projects by "Sayany" Ensemble created on the occasion of some important historical dates: "In the Cradle of the Sayans and Tandy" (for the $90^{\text {th }}$ Anniversary of Foundation of the People's Republic of Tuva, 2011) and "The Golden Arrows of the Dream" (for the $100^{\text {th }}$ Anniversary of the Union of Tuva and Russia ${ }^{2}$, 2014). I.O. Ondar defines their genre specificity as "close to ballet performance (presence of a single plot, common choreographic concept with some classic dance elements), but in the strict sense not conforming to the ballet criteria, but rather presenting an intermediary genre between ethnoballet, dance suite and an extensive vocal and choreographic performance with a storyteller (on the stage or behind)" (Ondar, 2016: 134). In our interpretation, the genre of these projects is defined as an "intermediary genre between ethnoballet, song opera and song-dance suite" (Karelina, 2017: 222).

Let us suggest that the listed elements of different known genre models do not truly clarify the genre specificity of the piece. For the reason of such situations ${ }^{3}$, in our common opinion (the author of the dissertation and the author of the article) it is more efficient to speak of syncresis of the second order (Ondar, 2016: 134, 141), being a re-interpretation ("remake" of a kind) of a syncresis of folk art, the contemporary professional creativity originates from and appeals to. As a term, syncretism normally describes an initial condition of a phenomenon, its essential integrity; however, to our mind, the synthesis of classic musical-theatre genres in contemporary Tuvan culture is re-interpreted to a great extent, since its elements (narrative, music, choreographic and spectacular aspects) are presented in a new quality, re-distributing functional load between themselves in a voluntary way.

\footnotetext{
In newspaper publication: Kyrgys, Z. (2018) "Zhuravlinaia skala" - udacha "Saian" ["The Crane Rock" Good Luck of "Sayany"], In Tuvinskaia Pravda [The Tuvan Truth], 14, February10.

2 In 1914, Russia Empire established its protectorate over Tannu Uriankhai (old name of Tuva). However, the programme dedicated to this event was criticized: "This new story has a right to exist; that's not argued. But it is not related to the $100^{\text {th }}$ Anniversary of the union of Russia and Tuva. It is a different story, a story of the past of the Tuvans $\langle\ldots>$ This programme radiates the love for the Scythian ancestors" (from newspaper article: Kenin-Lopsan, M. (2014). Zolotye strely mechty [Golden Arrows of the Dream], In Tuvinskaia Pravda [The Tuvan Truth], 105, September 20).

3 I.O. Ondar explains this phenomenon with the "sustainability of ethnocultural ideas in the Tuvan world outlook" (Ondar, 2016: 136).
} 
Comparing the three different music cultures (folklore, professional oral tradition music and composed music), in the series of features the ethnic music researcher S. Galitskaia determines as the "core" related to the character of functional ratio of the underlying parameters making any type of music creation possible (Galitskaia, 2015: 8). In her opinion, it is presented as follows: 1) in folklore, "the core has a syncretic character"; 2) in professional oral tradition music, "the core is a partial decay of syncresis"; 3) in composed music, "the core is complete decay of syncresis" (Galitskaia, 2015: 11). In this aspect, the typical tendency in contemporary Tuvan musical culture development looks "retrogressive", looking back at recovery of the initial syncresis partially found in the young orchestra practices (Tuvan National Orchestra and the Brass Band), when the composer and the performer present themselves as an inseparable integrity and, often, in a collective form.

The said projects of "Sayany" Ensemble have become collective pieces, since the music was composed by a group of young Tuvan composers (among them, there were: Buian-Maadyr Tulush, Choygana Kombu-Samdan, Urana Khomushku, Aiana Oiun, Aiana Mongush) ${ }^{2}$. At that, the music was composed in a close dialogue with the producer choreographers and the head of "Sayany" Ensemble instrumental group Eres Tartan-ool. Starting from the first similar theatre project, "Monge aialga" "The Eternal Melody", 2004), collective composing cooperation has become a typical phenomenon indicating the presence of a "Tuvan Mighty Group" (Karelina, 2017: 221). Despite the maximal style integrity of the episodes (previously explained with the young age of the authors, general trajectory of the professional education provided at Kyzyl College of Arts and Krasnoyarsk Academy of Music and Theatre, the closeness of their aesthetic platforms), the individual style of each composer is still vivid, contributing a share of diversity into the final creative result, quite prominent in the genre of the scenic whole.

The Tuvan National Orchestra established by the Ministry of Culture of the Republic in 2003, has been inclined to go beyond the traditional ideas of orchestra performance from the very beginning: one of the first performed pieces was "The Ballad of Igil", based on the folk legend of the most respected bowed instrument of the Tuvans, among the musicians known as "Tool" (a tale, a fairy tale) and performed as

Historically, folklore preceded professional music of oral tradition, which, in its turn, preceded the emergence of composed music. In Tuva, due to the specificity of the cultural and historical processes, these stages "overlapped" to a certain extent, which may possibly explain the contemporary Tuvan musicians' inclination to collective co-creativity in the framework of oral-written and written-oral professionalism.

2 Composing practice of the New European tradition is characterized with individuality; collective pieces are very seldom, often being a sort of a declaration of a new aesthetic platform (as with "The Mighty Group" in Russia, $19^{\text {th }}$ century, or the French "Les Six" of the $20^{\text {th }}$ century). 
a synthesis of music and word. Playing, singing ${ }^{1}$ and narrating, the orchestra positions itself as a collective incarnation of a storyteller (toolchu). A new version of telling a legend of another folk instrument (a struck-string zither) was presented in spring 2017, in "Chagadan" music performance ${ }^{2}$. Despite the theatrical presentation form, the components remain the same: the storyteller (toolchu), music (Tuvan Orchestra on the stage), singing (orchestra members), but the characters and the plot of the legend are visualized (theatre artists, stage, scenery). Formally, from the genre point of view, a musical performance is different from a concerted item, but, basically, what we see is just a new variation on the "syncresis of the second order".

A possible way of explaining the reasons for the emergence of such tendency leads us to throat singing (khöomei) again ${ }^{3}$. Perhaps, the key meanings should be sought for in the nature of khöomei, the acoustic features of which have been studied by a number of researchers ${ }^{4}$. Despite a certain argumentativeness of the statements of the social anthropologist M. Stelmaszyk (understandably, the author is far from music theory), the idea of the essential connection between the metaphysics of sound and the world model ${ }^{5}$ in Tuvan culture appears reasonable 6 . The author claims that "the Tuvan world and the realm of the ritual should be approached through the notions of homogeneity and unity rather than multiplicity" (Stelmaszyk, 2017: 119). Integrity, homogeneousness, indivisibility, syncresis are related (almost synonymic) terms. We suppose that further development of this discourse may bring its fruit.

Creative activity of the Brass Band of the Government of the Republic of Tuva established in 2008 from the very beginning was remarkable for its inclination for style experiments and modulations: the young musicians actively used various styles of

Half of the orchestra musicians have skills of throat singing of different styles.

The performance caused a mixed response of the specialists; the reference of culture and theatre researcher A. Kuzhuget was generally positive and the one of culture researcher and ethnic music theorist V. Suzukey was very critical: "it was not really Tuvan, but rather 'Scythian-Black Sea' type $<\ldots>$ The Tuvan colours and national specificity are totally blurred”. See newspaper articles: Kuzhuget, A. (2017). I orkestr v glavnoy roli [And the Orchestra Starring], In Tuvinskaia Pravda [The Tuvan Truth], 45, April 29; Suzukei, V. (2017). Islamskie motivy melodii "Chadagana" [Islamic Motives of "Chadagan" Melodies], In Tuvinskaia Pravda [The Tuvan Truth], 47, May 6.

3 As it has been proven in the process of Tuvan music history analysis, höomei is the central element of the ethnic musical culture and the whole system of Tuvan music genres (Karelina, 2009: 95-106).

4 In our research we relied on computer method of sound analysis co-authored by A.V. Kharuto (Karelina, 2009: 72-95), summaries in the article (Yunusova, Kharuto, 2016).

World outlook construction is presented by the author as "Tuvan Sociocosmic Politics" (Stelmaszyk, 2017: 119).

6 The author writes: "In this article, I sought to show that, similarly to the sound unit, the Tuvan world constitutes an introverted, inside oriented whole, where elements function in the closed interrelated and interdependent system. Consequently, I focused on the importance of sound and showed how the structure of the sound unit in throat singing offers an effective analytical framework to structurally grasp the occurrences during the shamanic rituals" (Stelmaszyk, 2017: 119). 
mass music culture (jazz, rock, rap, hip hop), mixing it with Tuvan folklore and classic repertoire. Moreover, the performing practice of the Orchestra has always involved some choreographic solutions.

Such performance form as a "marching concert" was also modified: within the military brass band performing tradition, the Tuvan band practiced two different options: the cavalry brass band defile and the orchestra performance in masks from the Buddhist mystery-play Tsam, successfully presented both in Russia and abroad. And though addressing the ritual Tuvan music form became a dominant trend in the musical life of the Republic, the appeal for the Tradition as such should be considered as an integrating element; in this sense, creation of a cavalry brass band acts as a revival of the historical experience of the Tuvan Revolutionary Army orchestra of the epoch of the People's Republic of Tuva.

The programme of the Tuvan Philharmonic Symphonic Orchestra dedicated to the $100^{\text {th }}$ Anniversary of the Union of Tuva and Russia performed on October 11, 2014 (on the significant date, the $70^{\text {th }}$ Anniversary of the People's Republic of Tuva admission to the USSR) demonstrated even a more complicated synthesis of genres. Even the name of the performance, "The Wind's Song of the Age of Change...", graphically reminded of the past, evoking various associations. The programme included some music pieces by Russian, Soviet and Tuvan classics, the Civil War songs, songs of the Tuvan volunteers, Russian and Tuvan folklore ${ }^{1}$. The programme began with throat singing (khöömei performer Alexei Khovalyg); a poem of Tuva was cited by Krasnoyarsk poet Sergei Vavilov, and at the end of the performance, an ensemble of the most famous Tuvan vocalists joined the orchestra. All these made a performance in the genre of a poetory, a vocal and symphonic composition on the crossroads of different styles. At that, the authors of the project managed to integrate music with video footage, creating, as journalist Nadezhda Antuf'eva expressed it, a new genre of "visual music"2. In the process of hard work with various archives (including the archive of the Ministry

Introduction: "The Tale"; Part I: "The Songs of Five Living Elements..." (Fire: music by A. Petrov for "Taming of the Fire" film; Earth: "Spring Rounds" and "Dance of the Earth" from "The Rite of Spring" by I. Stravinstky; Metal: Music by G. Sviridov to the film "Time, Forward!", Water: fragment from the Fantasy by A. Petrov to "Amphibian Man" film; Wood: "Taiga" from the suite "Our Tuva" by A. Chyrgal-ool); Part II: "Music of the Century..." (fragments from parts I and III "Le Divin Poème" by A. Scriabin, fragments from parts II and III of "Taiga Symphony” by V1. Toka, "Polyushko-Polye” by L. Knipper, "Oy, moroz, moroz" Russian folk song); Part III: "The Wisdom of the Centuries..." (Warriors... - song by L. Izarylevich "Tulchuushkunche!" (To the Battle!); Losses... "Foxtrot" from "The Golden Age" ballet by D. Shostakovich; Anniversary... Final from the "Festivity Suite" by R. Kendenbil; Shepherd... - Tuvan folk song "Aldan khoy").

2 See newspaper publication: Antuf'eva, N. (2014). Igor' Dulush i ego komanda rodili v Tuve ne bardak, a novyy zhanr - zrimomuzyku [Igor Dulush and His Team Gave Birth is not a Mess in Tuva, but a New Genre Visible Music], In Tsentr Azii [The Centre of Asia], 40, October 17-23. 
of Foreign Affairs of the Russian Federation), unique documents and footage were

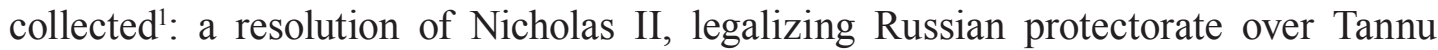
Uriankhai, Stalin, Hitler, Che Guevara, political prisoners, Baikonur, Gagarin, leader of Soviet Tuva Salchak Toka, the Minister of Defence of Russia and compatriot of Tuvans Sergei Shoygu, the People's Republic of Tuva arats, footage of contemporary life of the Republic etc. The video accompanying the music was conceptually intense, informatively saturated, and, first of all, deepening and revealing the profound musical meanings. To our mind, the project could be defined as a chronicle symphony or a video symphony, though, obviously, such definitions are not capable of expressing the total meaning of the final genre and style mix.

\section{Conclusion}

To sum up, let us remark that in the musical and spectacular projects of contemporary Tuva there is an obvious tendency to creative interpretation of the Past (which explains the selection of stories and means of expression), which is quite wide, and to integration of folk art elements, together with an inclination to the antient ritual forms. This is where the "crossover" phenomenon is manifested and the "complex and compound" genre mixes come from.

It is worthwhile stating the multiplicity of genre development processes in the music and spectacular genres of today's Tuva, that are mostly intuitive. The project authors always have difficulties defining the ultimate product, and so do researchers. For this reason, the suggestion of music theorist $\mathrm{O}$. Kulapina to develop a special terminological and methodological branches of music theory to avoid this "terminological collapse" seems reasonable (Kulapina, 2017: 10). Maybe, the presently suggested "syncresis of the second order" term could be included into the common music theory researches and get a clearer terminological definition.

The material studied herein is, to a great extent, a reflection of interaction and approach of the traditional, elite and mass cultures, characterizing the spiritual life of the contemporary society (Kostina, 2009). Tuvan creative experiments may be perceived as "a search for new texts in the interpretation of our far ancestors' world outlook" (Lomanova, 2015: 193), which has generally become a typical trait of artistic

\footnotetext{
I agree with the opinion of the video footage formulated by the journalist Marina Kenin-Lopsan: "This was a herculean task of processing the chronicles, not only Tuvan, but also Soviet and global. $<\ldots>$ The video matches the music so well, and the logical accents are so bright! $\langle\ldots>$ This is complete inter-penetration of music and video merged together" (Kenin-Lopsan, M. (2014). O veke peremen... [About the Century of Changes...], In Tuvinskaia Pravda [The Tuvan Truth], 117, October 18).
} 
life of the neighbouring Siberian regions. In this context, contemporary creativity becomes a channel transmitting axiological meanings of Siberian ethnocultures into the big world, highlighting Siberia as a special territory in Russian and global cultural spaces.

\section{References}

Beahrs, R.O. (2017). Nomads in the Global Soundscape: Negotiating Aesthetics in Post-Soviet Tuva's Traditional Music Productions, In The New Research of Tuva, 2, 59110, available at: https:/nit.tuva.asia/nit/article/view/716 DOI: 10.25178/ nit.2017.2.3

Galitskaia, S.P. (2015). O professionalizme v traditsionnoy muzykal'noy kul'ture [On Professionalism in Traditional Musical Culture], In Problemy Muzykal'noj Nauki [Problems of Musical Science], 4, 6-14, available at: http://journalpmn.com/index.php/ PMN/article/view/238/240 DOI: 10.17674/1997-0854.2015.4.006-014

Haynes, J. (2010). In the blood: the racializing tones of music categorization, In: Cultural Sociology, 4(1), 81-100, available at: https://www.researchgate.net/profile/ Jo_Haynes/publication/249830966_In_the_BloodThe_Racializing_Tones_of_Music_ Categorization/links/544114590cf2e6f0c0f59381/In-the-BloodThe-Racializing-Tonesof-Music-Categorization.pdf DOI: 10.1177/1749975509356862

Karelina, E.K. (2009). Istoriia tuvinskoy muzyki ot padeniia dinastii Tsin i do nashikh dney: Issledovanie [The History of Tuvan Music from the Falling of the Qin dynasty to the Latest Time: Research]. Tchaikovsky Moscow State Conservatory, Ed. by V.N. Yunusova. Moscow, Kompozitor Publishing House, 552 p.

Karelina, E., Ondar, I. (2012). V prostranstve mifa: rozhdenie detskogo etnobaleta v Tuve [In the Space of Myth: Birth of Children's Ethnoballet in Tuva], In Muzykal'naia zhizn' [Musical Life], 4, 85-87.

Karelina, E.K. (2017). Soiuz kompozitorov Tuvy: navstrechu 40-letiiu tvorcheskoy organizatsii [Union of Tuvan Composers: Towards the $40^{\text {th }}$ Anniversary of the Creative Organization], In Khudozhestvennaia kul'tura Rossii vchera, segodnia, zavtra: regional'nyi aspect [Artistic Culture of Russia Yesterday, Today, Tomorrow: Regional Aspect]. Krasnoyarsk State Institute of Arts, Ed. by N.A. Elovskaia. Krasnoyarsk, P. 218-222.

Karelina, E.K. (2018). The problematic aspects of cultural policy in modern Tuva, In Journal of Siberian Federal University. Humanities \& Social Sciences, 2018, 11 (2), 218-226, available at: http://elib.sfu-kras.ru/handle/2311/70369 DOI: 10.17516/19971370-0217. 
Kostina, A.V. (2009). Natsional'naia kul'tura - etnicheskaia kul'tura - massovaia kul'tura: "Balans interesov" v sovremennom obshchestve [National Culture - Ethnic Culture - Mass Culture: the "Balance of Interests" in Modern Society]. Moscow, LIBROKOM Book House, 216 p.

Kulapina, O.I. (2017). Problemnye voprosy sovremennoy muzykovedcheskoy terminologii [The Problematic Questions of Contemporary Musicological Terminology], In Problemy Muzykal'noy Nauki / Music Scholarship, 2, 6-13, available at: http://journalpmn.com/index.php/PMN/article/view/837/830 DOI: 10.17674/19970854.2017.2.006-013

Lomanova, T.M. (2015). Sibirskaia etno-arkhaika: drevnie mirovozzrenia skvoz' prizmu sovremennogo iskusstva [Siberian Ethno-Archaic: Ancient World Views Through the Prism of Modern Art], In Novaia art-kritika na beregakh Eniseia [New Art Criticism on the Banks of the Yenisei], Siberian Federal University, Ed. by N.P. Koptseva. Krasnoyarsk, P.181-193.

Ondar, I.O. (2016). Genezis i transformatsiia tuvinskogo tantsa v kul'ture Tuvy: diss. ... kand. kul'turologii; nauchnyi rukovoditel' E. Karelina [The Genesis and Transformation of Tuvan Dance in the Culture of Tuva: Dissertation for the academic degree of a Candidate of Cultural Science; scientific adviser E. Karelina]. Kyzyl, 179 p.

Shaposhnikov, M.V. (2017). Tuvinskaia muzyka i world music [Tuvan Music and World Music], In The New Research of Tuva, 2, 122-141, available at: https://nit.tuva. asia/nit/article/view/712 DOI: 10.25178/nit.2017.2.5

Stelmaszyk, M. (2017). From the sounds of throat singing to the sounds of shamanic practice: Structural organisation of shamanic rituals in Tuva, In The New Research of Tuva, 2, 111-121, available at: https://nit.tuva.asia/nit/article/view/713. DOI: 10.25178/ nit.2017.2.4

Stone, E.A. (2012). Genuine Tuvan: producing authenticity in the Republic of Tuva: Thesis Presented to the Faculty of the Graduate School of The University of Texas at Austin in Partial Fulfillment of the Requirements for the Degree of Master of Arts; supervisor T.J. Garza. Austin, 83 p., available at: https://repositories.lib.utexas. edu/handle/2152/26819 (accessed 04.07.2018)

Terada, M. (2017). Razvitie sovremennoy muzykal'noy kul'tury Tuvy (vzgliad iz Iaponii) [The Development of Contemporary Music Culture of Tuva (a View From Japan)], In The New Research of Tuva, 2, 210-218, available at: https://nit.tuva.asia/nit/ article/ view/707 DOI: 10.25178/nit.2017.2.11 
Yunusova, V., Kharuto, A. (2016). Computer Sound Analysis of Traditional Music of Transcaucasia and Central Asia, In Yearbook for Traditional Music, 48, 136-145. DOI: 10.5921/yeartradmusi.48.2016.0136

\title{
О тенденциях современной художественной культуры Сибири (на материале музыкально-зрелищных проектов Тувы)
}

\author{
Е.К. Карелина \\ Новосибирская государственная консерватория \\ имени М.И. Глинки \\ Россия, 630099, Новосибирск, ул. Советская, 31
}

Статья посвящена тенденциям в современной художественной культуре Сибири. Мировое признание получило музыкальное искусство горлового пения тувинцев, одного из коренных сибирских этносов. Новейшие события музыкально-культурной жизни в Туве еще не становились объектом музыкознания, поэтому статья обращена к явлениям музыкальной культуры Республики Тыва последнего десятилетия. Рассматривается проблема жанровой природы в современном искусстве Тувы. Методология исследования опирается на системный подход в сочетании музыковедческих и культурологических методов анализа. Целью статьи стало определение жанровой специифики музыкально-зрелищных проектов. Материалом послужили музыкально-театральные и хореографические постановки, а такэе концертные программы оркестровых коллективов (тувинского национального, духового и симфонического оркестров). В прочессе анализа этнобалетов, программ национального ансамбля песни и танияа «Саянь» и тувинского национального оркестра отмечается тяготение к глубинным основам этнокультуры и выдвигается понятие «синкрезис второго порядка». Для творческих проектов духового оркестра характерно проявление феномена «кроссовера». Особый жанровый микст (музыкально-визуально-поэтический) воплотился в проекте симфонического оркестра «Песнь ветра века переменъ...». В результате, различные варианты жанровых модификаџий в музыкальном искусстве Тувы оцениваются с позиции сложного взаимодействия различных типов культур и поиска новых смыслов в обращении к этноархаике. Современное творчество в данном русле - своего рода канал транслячии ценностных смыслов сибирских этнокультур в мировое культурное пространство.

Ключевые слова: Сибирь, Тува, современная культура, музыкально-зрелищные проекты, этнобалет, кониертные программы, синкрезис второго порядка, жанровый микст.

Научная специальность: 17.00.00 - искусствоведение, 24.00.00 - культурология. 